\title{
The Culture of Caring for the Sick in the Community in Flores, Sumba, and West Timor of East Nusa Tenggara, Indonesia
}

\author{
Aemilianus Mau ${ }^{1 *}$, Enie Noviestari ${ }^{1}$, Krisna Yetti ${ }^{1}$, Tutik Sri Hariyati ${ }^{2}$, Dewi Gayatri ${ }^{1}$ \\ ${ }^{1}$ Department of Basic Nursing, Faculty of Nursing, Universitas Indonesia, Depok, West Java, Indonesia; ${ }^{2}$ Department of \\ Management of Nursing, Faculty of Nursing, Universitas Indonesia, Depok, West Java, Indonesia
}

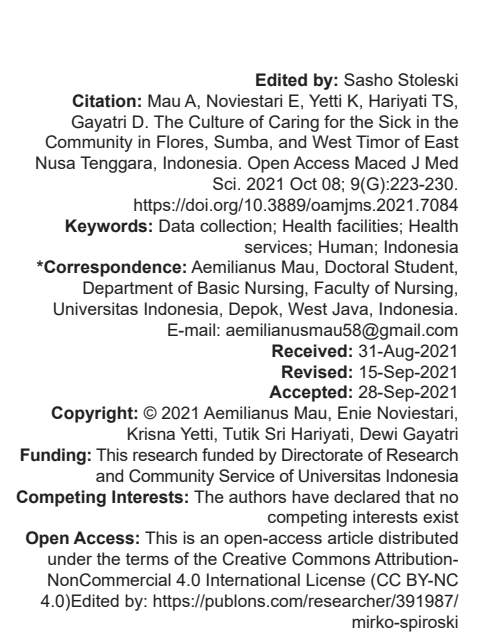

\section{Abstract}

BACKGROUND: The people of East Nusa Tenggara (NTT), especially Flores, Sumba, and West Timor, have a diversity of local cultures regarding health conditions, illness, and care for the sick.

AIM: This study aimed to explore the distinctive culture of caring for the sick that belongs to the people of Flores, Sumba, and West Timor, NTT.

METHODS: This study used the descriptive phenomenology method. The participants of this research were community leaders. Data collection was carried out from August 20, 2020, to October 10, 2020, through in-depth interviews with community leaders. Data analysis was carried out through the following stages: verbatim transcribing determining keywords, assigning categories, and determining themes.

RESULTS: The thematic analysis found three themes, in which one the community viewed health as a condition where a person shows no signs and symptoms of disease and is able to carry out daily activities, (2) the community believed that the cause of disease comes from medical and environmental factors, while non-medical factors are from God, Nature, and Spirits, and (3) the community's efforts to heal the sick included going to health facilities, providing traditional treatment, performing traditional rituals, and praying.

CONCLUSION: The people of NTT use complementary approaches (traditional and conventional) in caring for the sick.

\section{Background}

The Indonesian province of East Nusa Tenggara (NTT) is one of the archipelagic provinces in this country with a total of 1,192 islands ( 43 inhabited islands and 1,149 uninhabited islands), consisting of four large islands, namely, Flores, Sumba, Timor, and Alor (FLOBAMORA), which includes 22 regencies/cities with a population of $5,287,302$ people [1], [2]. The population of this province is mostly Catholic and Protestant $(90.9 \%)$, while the rest is Muslim (8.8\%), Hindu (0.04\%), and Buddhist $(0.08 \%)$ [3], [4]. This province has a rich cultural diversity in the form of customs, traditions, arts, and languages, consisting of 16 ethnic groups with approximately 35 regional languages [4]. The various cultures of the people of NTT provide different perspectives on health conditions, illness, efforts to improve health, and efforts to prevent and treat diseases [5]. Some research results show that the NTT community has less-resilient health viewpoints due to the numerous health problems, such as the high Maternal Mortality Rate, Infant Mortality Rate, Toddler Mortality Rate, and number of stunting toddlers [3], [4], [6]. Although health facilities such as hospitals, health centers, and sub-district health centers are currently available in every sub-district and village, the community still adheres to the culture of care based on their ancestral heritage [6], [7], [8].

Cultural factors are closely related to community morbidity and mortality [5], [6]. The results of a study show that the determinant factor of health culture in the prevalence of pulmonary tuberculosis (TB) disease in Roe Ndao district is the public's perception of illness that pulmonary TB is a hereditary, hossa, and non-communicable disease. Some norms include betel nut as a treat for guests, traditional se'i houses, and traditional se'i belief that newborns should be smoked for 40 days in a house with dirt floors belonging to nearly $50 \%$ of the population. The norms and stigma among the community in Pariaman city perceive pulmonary TB as a disease caused by tamakan, or black magic from a hater, and there is evidence that the community West Sumatra, in Kota Pariaman, norms, stigma, fear, and shame as TB sufferers shape public's perceptions of this illness that they still call it a prolonged cough, 40-day cough, dry cough, or asthma. The belief of the people in West Lombok Regency of West Nusa members have a habit of spitting in random places. In 
Tenggara Province is that if they drink Kiai Datuk Ismail's used drinking water, they will obtain healing [9].

A pregnant woman who has special dietary and drinking restrictions during pregnancy has a 5400times risk of giving birth to a low birth weight (LBW) child compared to one who does not abstain from certain foods and drinks. Unhealthy eating habits during pregnancy have 4,333 times more risk of giving birth to LBW babies. Pregnant women who do not have their pregnancy checked regularly at health facilities have 4457 times more risk of giving birth to LBW newborns [10]. The cultural factor influencing infant mortality in the district of Kupang and district of Ngada, NTT is the se'i culture which is the Timorese tradition that requires postnatal mothers to remain near coals of fire (being smoked) for 40 days in a dusty house on stilts with poor lighting and ventilation. Other factors are the lack of the husband's support for pregnant women to check their pregnancy and give birth in adequate health facilities as well as the lack of attention from the village government in the form of establishment of a Village Regulation which requires every pregnant woman to give birth in decent health facilities [8]. This study aimed to explore the distinctive culture of caring for the sick that belongs to the people of Flores, Sumba, and West Timor, NTT.

\section{Methods}

This research is a qualitative study with an exploratory descriptive approach. The participants of this study were community leaders purposively selected according to the research criteria of completing a minimum of primary education, acting as customary leaders, government stakeholders, and religious leaders from Flores, Sumba, and West Timor, having experience of being hospitalized or becoming a caregiver for sick people, and being willing to participate. The research instrument was the researcher himself and the semistructured interview guide. Written informed consent was obtained from each respondent in accordance with the guidelines of the faculty of Nursing Universitas Indonesia, the National Health Research Ethics Commission, and the Declaration of Helsinki. The faculty of the Nursing Universitas Indonesia Ethics Committee issued the ethical approval. The research number was: SK-244/UN2.F12.D1.2.1/ETIK 2020. Data collection was carried out after passing the ethical review from the Faculty of Nursing of Universitas Indonesia (FIK UI), obtaining a research permit from FIK UI, obtaining a research permit from the Integrated Licensing Office of NTT Province, and obtaining a research permit from the Integrated Licensing Office of Malacca Regency, West Sumba, and Ngada. Before data collection, the researcher introduced himself and then explained the objectives, benefits, and research procedures to the participants. Participants who agreed to be involved in the study signed the informed consent. The researcher excluded the participants' name, and the research data were stored properly by the researcher (hard copy and soft copy documents were known by the researcher only). The interviews were conducted in traditional houses and participants' homes that met the security and comfort requirements. Data collection was carried out from August 20, 2020, to October 10, 2020, using a semi-structured interview guide assisted by a voice recorder to record the researcher's interviews with the participants, cellphone cameras to photograph the researcher's interviews with the participants, as well as notebooks and pens to record the interview results. The researcher paid attention to the bracketing aspect and trustworthiness of the data. The bracketing aspect was done by giving open questions and giving the participants the opportunity to answer the researcher's questions as they were, without commenting on or directing the participants' answers. The aspects of data trustworthiness consist of credibility, dependability, conformability, and transferability. The aspect of credibility was obtained by conducting a trial interview on five participants before the implementation of data collection, selecting participants from three groups of community leaders, namely, (1) traditional stakeholders, (2) government stakeholders, and (3) religious stakeholders, and providing an opportunity for the participants to correct the results of interview transcripts. The dependability aspect was obtained by interviewing each participant using the same interview guidelines. The results of the transcript of the first participant were used as a lesson learnt for the subsequent participant interviews until data saturation occurred. The conformability aspect was achieved by reconfirming unclear/incomplete data to participants, after which the research data were reviewed by the research team. The aspect of transferability was achieved when the results of this study could be applied to other areas with the same characteristics. Data analysis was carried out through the following stages: Verbatim transcribing, determining keywords, assigning categories, and determining themes. Data saturation was obtained from the tenth participant, but to ensure that no newer categories and themes were found, the researcher added four participants.

\section{Results}

\section{Characteristics of participants}

The participants in this study were 14 community leaders consisting of six traditional stakeholders, two government stakeholders, and six religious stakeholders. They are people from Flores, 
Sumba, and West Timor, 12 people are male and two are female aged between 34 and 85 years. Their occupations are farmers, builders, state civil apparatus, private employee, pastors, and ustaz (Muslim teacher). Some are married, but some are single. Their education ranges from elementary school to college graduates. They are Catholic, Protestant, Muslim, Hindu, and adherents of the Merapu faith.

\section{Thematic Analysis and Discussion}

Based on the results of the thematic analysis, three themes were obtained, in which (1) the community views health as a condition where a person does not show signs and symptoms of disease and is able to carry out daily activities, (2) the community believes that the cause of disease comes from medical and environmental factors and non-medical factors come from God, Nature, and Spirits, and (3) the community efforts to heal the sick are to go to health facilities, provide traditional medicine, perform traditional rituals, and pray. The results of the thematic analysis of this study are described as follows.

The community views health as a condition in which a person shows no signs and symptoms of disease and is able to carry out daily activities

In the interviews with the participants, especially the traditional stakeholders, it was found that they generally find it difficult to define health and illness according to their cultural understanding. In general, they define health and illness in a simply way. According to the local people, a person is said to be healthy if he does not suffer from a certain type of disease as evidenced by the absence of signs and symptoms of illness, such as fever, headache, nausea, vomiting, weakness, and other complaints. Healthy people are able to properly perform their daily activities.

"If a person is considered healthy, then that person does not show signs and symptoms of illness..." (P14)

"...isin laran la no moras (There is no disease in the body)..." (P2).

“...Weki Dhe Modhe (Healthy body)...” (P6)

"... Health is always understood as the ability to work and enjoy everything..." (P11)

“...Sehat nee berarti ema bele karian, bele lao, bele halai, betur, toba, bele hananu (healthy means people can work, can walk, can run, can sit, can sleep, can sing)... (P3).

Health according to the Timorese is "isin laran la no moras" (There is no disease in the body). In their opinion, a healthy individual is clean from disease, declared whether by a shaman or by a doctor. The Ngada-Flores people emphasized the same thing that a healthy person has "Weki Dhe Modhe" (healthy body) and does not suffer from any types of disease. Furthermore, the Sumbanese said that healthy people show no signs and symptoms of disease. According to the Sumbanese, each type of disease causes typical signs and symptoms such as fever, nausea, vomiting, headache, weakness, and other complaints. Furthermore, all Timorese, Flores, and Sumbanese agreed that healthy people are able to carry out daily activities well, such as being able to work (bele karian), walk (bele lao), run (bele halai), sit (tur), sleep (toba), and do other normal activities. The results of this study illustrate that the people of NTT understand a healthy condition as the condition of the body that is free from disease, shows no signs and symptoms of disease and is able to carry out activities properly according to their social role in the community. This research is in line with research on the perceptions owned by the West Timorese Tetun community toward health and illness. In their understanding, health is a condition that is normal and good (di'ak), and not sick (la moras). Illness is defined as a condition where people feel unwell (horan isin la di'ak) or feel sick (moras) or suffer from disease (kona horak). According to the understanding of the community, a person is said to be sick if he has typical signs and symptoms such as physical weakness, making him unable to carry out physical activities as usual [11]. The Kebahan Dayak Ethnic Society has a similar perception to the results of this study. According to these people, a person is said to be healthy if he has a healthy body, a strong mentality, and is able to move smoothly without interference [12].

Health is seen as something dynamic and fluctuating, sometimes healthy, sometimes sick, depending on various internal and external factors. According to the people of NTT, being healthy depends on several factors, including achieving a balance between activity and rest, consuming nutritious food, exercising regularly, thinking positively, praying, and being grateful to God. This is based on the statements of two participants as follows.

"...Always be grateful, eat foods that contain four healthy five perfect foods, exercise, have an adequate rest according to age, always think positively of anyone, and most importantly always remember God, don't wait to get sick then remember God... (P9, P12).

“...We must rest regularly, eat regularly, exercise. I think this is an important thing while continuing to pray so that God will take care..." (P14).

The opinions of the two participants above are in accordance with the current conditions where there is a tendency of people to be lazy to move/lazy to exercise (sedentary lifestyle). This condition is at risk for the occurrence of several types of disease due to lack 
of movement (hypokinetic condition), such as coronary heart disease, hypertension, atherosclerosis, diabetes mellitus, osteoporosis, low back pain, easy fatigue, and other types [13]. Conversely, in people who do regular exercise, have good body muscle strength, and good heart-lung endurance, their blood pressure will remain normal, blood sugar levels are controlled, and weight is balanced. This condition will keep people healthy and fit [9]. The recommended exercise at home during this COVID-19 pandemic is aerobic and anaerobic with moderate and regular intensity. This type of exercise is beneficial to improving the immune system, metabolic health, and mental health [14].

The next factor to consider to stay healthy is the need for age-appropriate sleep. The average adults sleep $7.5 \mathrm{~h}$ per night, while children's need for bedtimes varies depending on their age. For infants, most of their activities are sleeping, while the need for sleep decreases with age. Sleep is highly beneficial for restoration (recovery) function and to maintain physical fitness. Adults with sleep deprivation will experience various physical complaints, such as fatigue, hypersensitivity to discomfort or pain, decreased psychomotor, unstable emotions, impaired memory, and decreased concentration [15], [16]. Children with inadequate sleep can experience behavioral and emotional changes as well as decreased immunity which have an impact on growth and development [10].

Another as important factor to maintain physical and mental health is positive thinking, praying, and being grateful. The mind affects physical and mental health. More than $90 \%$ of the mind affects all parts of the body while more than $75 \%$ diseases come from an individual's negative dialogue with himself. Negative thoughts will affect the nervous system, cardiovascular, and immune systems which have an impact on the occurrence of hypertension, stroke, autoimmune, and cancer. Patients treated with laughter and positive news could have $35 \%$ recovery [17].

When sick people think positively, smile, are optimistic and laugh, the level of endorphins in the body increases. Endorphins are happy hormones which are particularly useful for boosting the immune system. In contrast, people who think negatively tend to get stressed, thus leading their body to produce stress hormones (cortisol) which affect the decline in the immune system [17]. When individuals experience a disease that requires long-term treatment and medication, such as tuberculosis, they are highly susceptible to stress, anxiety, and depression. To reduce these negative feelings, physical and mental relaxation through prayer and gratitude are required. A number of research findings show that prayer activities have a reducing effect on stress, anxiety, and depression. Prayer stimuli will result in a decreased heart rate, reduced brain waves, a decreased respiratory rate, reduced blood pressure, and a decrease in the overall metabolic rate. This condition will make the body become more relaxed (relaxation response). A relaxed body will stimulate the brain to produce the hormone enkephalins or endorphins of which chemical compounds are responsible for happiness. Endorphins are produced by the pituitary gland when an individual has an adequate rest and feels happy or laughs. Endorphins are beneficial for controlling persistent aches and pains, managing stress, and boosting the immune system [18].

\section{The people believe that the cause of disease comes from medical factors and non- medical factors from god, nature, and spirits}

According to the belief of the people of NTT, a person is sick or experiencing a type of disease caused by two factors, namely, medical factors and nonmedical factors. Medical factors are factors that can be identified through medical procedures, such as history taking, physical examination, laboratory examinations, and other supporting examinations. The cause of the disease is related to the pathological agent of the disease. Meanwhile, non-medical factors are factors that occur outside of medical procedures and are difficult to prove medically, such as suanggi, possessed by evil spirits, illness due to violations of traditional traditions, a fine for sins/curses, anger of regional authorities, and anger of the ancestors. The following is an excerpt from the community's views.

"...The Catholic Church believes that there are medical and non-medical ailments such as dark forces, demonic influences. There are three factors that affect sick people, first from God, second from Nature, and third from the Spirit, in short 3A (Allah, Alam, Arwah)." (P9)

"... The belief of the Malacca people is that illness is caused by a light factor (kroman), dark factor (kukun); black magic (ema ralo), angry ancestor (matabian krakat)..." (P3).

"...The cause of a person being sick according to the Sumbanese consists of three factors, namely angry God (Mori), Ancestor (Tomate), Territory Guard (Mori Tana)..." (P10)

"...If we are sick, we think of three ways, sir, whether it is customary, poison, devil or suanggi. If the pain is too severe, sir, we can pray and see also in the strings of the intestines of a chicken, if there are a few grains, we Merapu people believe that there is no hope, we are ready..." (P7).

“...The cause of illness or disaster according to the belief of the Ngada people is that there is a violation of customary rules/traditions, wrongdoing/sins..." (P4).

The expressions of the five participants above illustrate that the NTT community still holds fast to the belief in the existence of non-medical elements which cause illness to a person. They attribute illness to 
black magic (suanggi), which in Tetun is called buan, in Bajawa it is called polo, and in Sumbanese it is called To Marang. The next cause is the angry territory guard. According to their belief, every place has a guard, and even every living creature on earth has a guard and protector. These guards have names in different regional languages. West Tetun people call them Rai Nain, Sumba people call them Mori Tana, and Bajawa people call them Nitu Zale. Another cause of illness/ disease is the ancestor's anger. The Tetun people of West Timor say "matabian krakat," the people of Sumba say "tomate mbani," and the Bajawa say "ine ebu naji". The next non-medical cause is pain that comes from God (Maromak/Mori/Ema Dewa). According to the belief of the people of NTT, illness is a warning from God to sick people to repent. Sickness is defined as a sacrifice for sin, and pain can also be interpreted as God's destiny. Meanwhile, the last non-medical cause is spirit possession. According to the belief of the people of NTT, a spirit possessed is a person whose body is entered by another spirit such as a genie which in the local language is called rai nain sae, mori tana, nitu zale, or possessed by the spirit of a person who has died (matabian sae/kukun toma/mata bejo/tama nani). When possessed by an evil spirit, a person will experience serious illness, can experience mental disorders, and can even die. Meanwhile, possession of ancestral spirits usually contains good messages in the form of advice to live in harmony or do the work that the family has forgotten, such as repairing the ancestors' graves, reconciling hostile families, or performing certain traditional rituals. The community also believes that if a tribal member sells heirlooms in their traditional house, 1 day that person will experience illness, an accident, or an unnatural death. If not purified by custom, the curse will also occur in the next generations [19], [20].

Indonesian people, especially those in rural communities, generally still have the same beliefs as the NTT people about the causes of disease from these non-medical factors. Javanese people are known as religious people, but in their daily behavior they still believe in mystical matters. One of the beliefs of the Javanese people is the belief in witchcraft. Witchcraft is a negative energy which can damage a person's life in the form of illness, household destruction, and even death. In addition, they also believe in the existence of wangsit. Wangsit is often referred to as inspiration, guidance, words, guideline, command, or magical "whisper" from God Almighty. Only the chosen people are able to receive wangsit, those who are diligent in getting closer to God Almighty, seeking the essence of life, and carrying out the so called laku or actions. Laku is the practice to perform various types of fasting, such as abstaining from all food and drink for a certain period of time, mutih or eating only white rice, ngrowot or only eating fruit, etc. Javanese people also believe in the power of spirits such as animism, dynamism, and totemism [21]. Similarly, Maryanti (2016), in her research on epilepsy and culture stated that epilepsy, which is a central nervous system disorder characterized by spontaneous and periodic seizures, is interpreted differently by the community in different countries. Epilepsy is defined as a form of religious experience associated with demonic disease and referred to as a sacred disease, is considered an attack by spirits or the state of being possessed, associated with evil spirits, black magic, witchcraft, or poisoning, associated with spiritual experience, and even considered as mental disorder [6].

The belief of the people of NTT about the causes of illness/disease in the context of traditional medical system is universally similar to the culture of the Dayak, Papua, Sulawesi, Javanese, and other ethnic cultures in Indonesia, where the etiology of disease is perceived personalistically and naturalistically. Personalistically, people believe that disease comes from active personal agents, such as supernatural beings (supernatural creatures), non-human beings (ghosts, ancestral spirits, evil spirits), as well as human beings (magicians, sorcerers), in which sick people are victims of these active agents. Then, naturalistically, disease is explained in a personal systemic term, recognizing the existence of a balance system in the body, such as heat, cold, body fluids, yin and yang, and being in a state of balance according to age and environment. If the balance is disturbed, it will lead to disease [22].

\section{The community efforts to heal the sick} are to go to health facilities, provide traditional medicine, perform traditional rituals, and pray

Based on the community's belief in the causes of the disease, their efforts in curing a disease are classified into three groups comprising (1) community groups who only seek traditional healers, such as shamans, massage therapists, and prayers, (2) community groups who seek treatment of disease from health facilities, such as from Puskesmas (primary healthcare center) or hospital, and (3) community groups who go not only to health facilities but also to traditional healers. This third group is the largest group in NTT with several participants stated the following.

“...In addition to going to community Health centers/hospital, families also perform traditional rituals to heal the sick, pray, and pin their hopes to Dewa Zeta (God), Nitu Zale (ancestor), because according to traditional beliefs, God is in the sky, ancestors are below the earth... (P4).

“...Using modern therapy at community Health centers/hospital, traditional ingredients (leaves and roots), traditional ceremonies (hamo mama), and prayer... (P2, P3)

"...The habit of Sumbanese in the village a sick person is not immediately taken to community Health centers or hospital, but the custom is to call a shaman 
to treat the sick person with a mixture of leaves, roots, and tree bark, which are boiled and the water is drunk and used for bath. There are also ingredients that have been processed from leaves, roots, and skin soaked in coconut oil to drink and smear on the sick part of the body. If it does not work, the family will call Tua Adat to make the custom..." (P10).

"...Well, if this illness must be treated, because this illness is caused by several factors, maybe because of eating, lack of rest, lack of exercise, therefore the treatment needs a kind of doctor who knows what disease we are diagnosed with, once again we keep praying because we believe that God heals..." (P14).

"... If you are sick, the effort that must be made is to go to a doctor (medically) and don't rush to take it to a shaman; in addition to going to a doctor, you must ask for God's strength, so that you will be given strength and healing..." (P12).

"...Catholic belief is "Medicus Curat, Deus Sanat:" Doctors Heals, God, Heals. Healing from illness is closely related to medical efforts and faith, namely complete surrender to His will..." (P8).

Local people still have the habit of treating the sick in addition to going to health facilities since they also perform traditional rituals such as asking for healing from Dewa Zeta (God), asking for help from the ancestors (Nitu Zale), and using traditional ingredients from roots, leaves, or tree barks which are nutritious to cure certain diseases. The traditional healer is usually a shaman. To date, the community has been combining traditional rituals with treatment in health facilities to support patient healing. Different conditions, however, are experienced by government officials and some religious stakeholders. In their opinion, if people are sick they must be treated by a doctor because it is the doctor who has the ability and authority to diagnose the disease and provide treatment according to the type of the disease. In addition, patients should also have adequate rest, eat nutritious food, and pray as an effort to support the healing process of the disease.

The community usually integrates local culture into care for sick people, especially for those who experience chronic/critical/terminal illness. In addition to undergoing medication/treatment at the hospital, the community performs traditional rituals such as "hamo mama or haleka mama" (serving betel-nut) to their ancestors asking for protection and safety for the sick. They believe that the ancestors are close to God, making them able to convey family requests to God to help heal the sick. In addition, they also believe that with God's permission, the ancestors also have the ability to heal the sick.

One participant stated that if the cause of the disease is balck magic (suanggi), then doctors and other health workers are unable to cure it, so there needs to be a traditional therapist such as a shaman/ prayer. Below is his statement.
"Nu ema nalo to, ema nalo ita treatment la diak hai to (like if people make it, doctor's treatment doesn't heal), Nia hodi ida tau ba once (as soon as the antidote is given, it heals immediately)".

According to the participant, a person who is sick due to suanggi/black magic cannot be cured by medical/conventional methods. Local people believe that shamans/prayers are the people who can heal the sick through giving potions, chanting mantras, and performing certain rituals. Therefore, the help of a shaman is also important, and it should not be prohibited (keta larang oli) as long as it does not conflict with medical principles. Especially when there is a terminally-ill person, or even a dying man, it becomes a strong culture. Nudar moras tia, mais no ema nee, ita hamo mama ba, hodi kaba iha uma moras (for example, the community performs a ceremony to serve betel nut to their ancestors then smear it on the patient's forehead at the hospital, nurses should not forbid it) because the purpose of such ritual is bodik hatama hika kmalar (the purpose is to return the spirit of the terminally-ill person into his body). This ritual is in fact a "prayer of supplication to the ancestors and God uttered in a traditional way". The customary prayers are as follows: "Matabian sia Tuan no nurak, nain Tuan sia, didin Tuan sia, iha kfitun fohon, iha fulan fohon, bodik atan oan na netan no susar no lia moras at, rinu at, sai nela nia isin ne, nia diak too loron ba loron, sehingga atan oan aa bele is free from nosi moras nee (Old and young ancestor, kings, who are above the moon and stars, for this servant of yours, who is in trouble because of this bad illness, these bad symptoms, go out of his body, he will be healed day by day, so your servant may be free from this disease). Halon hodi fiar, lafiar hai ladadi (Ask with full trust, if you do not believe it, it will not happen/come true).

There is also a ritual to regain a person's spirit that has left the body as a result of falling from a vehicle or a tree. According to the local people's beliefs, when a person's body is hit hard on the ground/asphalt/floor/ other objects, the person's spirit will come out of the body, causing the body to stiffen. If the spirit is not told to reenter the body, then the person is likely to die.

"...I think a lot of cultures here teach us about humans, but there are numerous misinterpretations as shamanic works, there are many, for example, people fall down, then they take some water, sprinkle it on the ground or where they fall, what does that actually mean? In fact, there is a local wisdom that the soul of a child who falls or stumbles is knocked out of the body and then requested to return to his body, and don't sleep there, you have to go back because there is a lot of experience that people who stumble will become stiff, even when they are treated using a modern or traditional method or traditional ceremony, they remain stiff, why? Because their soul is still there or still at the scene, it must be sent home..." (P8).

In addition to performing traditional rituals, the community also prays for healing from God. They 
believe that healing from disease comes from God not only because of the ability of doctors or other health workers. They are only intermediaries/tools/ messengers of God to save the lives of the sick. Here is their statement.

“...Medicus Curat, Deus Sanat”: Doctor Heals, God Heals..." (P8).

"...Doctors are good at medicine, but the healing of diseases is God's intervention..." (P12)

“...We keep praying because we believe that God heals. Doctors and nurses are only God's tools/ intermediaries to save others. So, the term of care for the sick must use ora et la bora, pray and work..." (P14).

Culture researchers, as well as writers such as Antonius (2011), Neonbasu (2013), and Tule (2019), explained that the Timorese, Flores, and Sumba ethnic people not only believe in their religion but also remain to live and practice their authentic religious belief, which is the belief in supreme beings and spirits, ancestral spirits, and spirits of the inhabitants of heaven and earth. Antonius [23] referred to the highest being as "The Most High," while Neonbasu [19] and Tule [20] referred to it as the "Divine One" who reigns over the heaven and the earth. Local people in these three ethnic groups refer to the highest form as Maromak (Tetun), Usneno (Dawan), Dewa Zeta (Bajawa), and Mori (Sumba) in their local language. The Tetun people of West Timor often refer to the highest form as "iha fitun fohon, iha fulan fohon, lolo liman la too, hakat ain la too" (which is above the stars and the moon, raise your hands but it is out of reach, raise your feet and it is still out of reach). According to the local community's belief in these three ethnicities, in order for humans to live securely, healthily, and safely, they must build a harmonious relationship with the highest being, the ancestors, the inhabitants of the earth, and the inhabitants of the heaven. Humans also have to live well and rightly by not destroying the nature of His creation and by performing prayers and offerings through the traditional rituals of each ethnic group in their traditional houses [19], [20], [23].

The people of Malacca have a special traditional house for a ceremony dedicated to the highest form, which is usually called "Uma Metan Maromak or Uma Maromak Oan" (House of God/House of the Son of God). This traditional house is believed to be a very sacred place which is only entered by certain people at certain times. If a person whose life is awful and erroneous enters this house, he will be cursed in the form of harm, illness, and even death. This traditional house is used as a house/place of prayer to convey all requests to the Most High, such as asking for rain, the rain to stop, abundant crops, or help for the healing and safety of the sick as well as other needs. If the prayer is appropriate, the request is quickly granted. For example, asking for rain in the summer, stopping heavy rain in the rainy season, or avoiding flash floods and other problems. This is the reason why local people believe in their authentic beliefs more than in their religion. Traditional house is only owned by an ethnic group, and in the past, it became the (sub) center for the Liurai kingdom, such as in the village of Laran, Builaran, Loro Dirma, or other Loro in Malacca Regency [24]. The same condition is found in the Ngada-Flores ethnic community and the Marapu people in Sumba. Especially among the Merapu believers, they still adhere to their authentic beliefs by not following any of the five religions in Indonesia. They have their own house of worship and have a priest called Rato. Local people believe in ancestral interference in human life. The ancestors who have died are believed to live in form of spirits and become intermediaries between humans with the highest being [25].

The Marapu faith respects the spirits of their ancestors as the intermediaries to worship the Most High (Highest Being). Ancestral spirits are believed to carry messages from humans to the Most High and provide answers from the most high to humans. Apart from acting as intermediaries, the ancestors have the task to represent the most high to provide help and protection for humans. In addition, they have mandate from the most high to punish guilty humans. Based on this understanding, local people still perform rituals to honor ancestral spirits and also ask for help for various matters, including the efforts to heal the sick [25].

The people of these three ethnic groups have common belief in the existence of spirits other than the human spirit, which are referred to as spirits. These spirits usually inhabit places such as large trees or boulders and empty houses. The local ethnic Timorese, Bajawa, and Sumbanese people refer to these spirits as Rai Nain, Ne'e Dhe Mori, and Mori Tana (Territory Guard). There are good guardians of this territory, but there are also bad ones. The good ones are believed to be able to help humans by providing white magic to treat or save the sick. Evil spirits usually called demons are those who often disturb humans, harm them, and make people sick and dead. People who are allied with this evil spirit will use black magic to make trouble for others [20]. Local people also believe that, by giving offerings to the spirits who guard the area, they will be saved from all disasters and dangers [23]. They also believe that the nature has a guardian, including the medicinal plants used to heal the sick. Therefore, every shaman who wants to take the roots or leaves of medicinal plants always performs certain rituals to ask for permission from the owner, thus allowing the medicinal plants to be able to heal the sick [11]. This study is in line with the research by Lesmana et al., which explains that the culture of Tidung Tarakan community to care for the sick is performed through three approaches, namely, (1) using herbal medicine/herb, (2) asking for prayers/ reading mantras (supernatural) by traditional healers, and (3) using a combined approach. Only when these three approaches fail do they ask for help from health workers [26]. 


\section{Study limitation}

Given the large number of tribes and ethnic groups in each community, the researcher did not involve all of their representatives as the research participants.

\section{Conclusion}

The people of West Timor, Flores, and Sumba NTT believe that the cause of a person's illness is medical factors and non-medical factors from God, Nature, and Spirits (3A). This belief remains very strong and is continuously passed down from generation to generation. When people are sick, in addition to going to health facilities, they also make efforts by seeking traditional medicine, traditional rituals, and prayers.

\section{Acknowledgement}

The authors thank the Directorate of Research and Community Service of Universitas Indonesia for funding this research.

\section{References}

1. Central Bureau of Statistics of East Nusa Tenggara Province. Health Statistic of East Nusa Tenggara. Kupang: Central Bureau of Statistics of East Nusa Tenggara Province; 2018. https://doi. org $/ 10.26911 / \mathrm{mid}$.icph.2018.01.20

2. Central Bureau of Statistics of East Nusa Tenggara Province. Health Statistic of East Nusa Tenggara. Kupang: Central Bureau of Statistics of East Nusa Tenggara Province; 2020. https://doi. org/10.26911/mid.icph.2018.01.20

3. Indonesian Ministry of Health. Indonesia Demographic and Health Survey 2012. Jakarta: National Population and Family Planning Agency Central Statistics Agency, Ministry of Health; 2013. https://doi.org/10.17501/24246735.2018.4105

4. Yuliawati S. Measurement of the socio-cultural aspect of East Nusa Tenggara. J Penelitian Evaluasi Pendidkan. 2011;15(1):13954. Available from: https://www.journal.uny.ac.id/index.php/jpep/ article/view/1091/1143 [Last accessed on 2021 Mar 06]

5. Mere DM. East Nusa Tenggara Health Profile 2018. Kupang: Provincial Health Office East Nusa Tenggara; 2018. https://doi. org/10.26911/mid.icph.2018.01.20

6. Maryanti NC. Epilepsy and culture. Bul Psikol. 2016;24(1):22-31. https://doi.org/10.22146/bpsi.16358

7. Nugraheni H, Wiyatini T, Wiradona I. Textbook of Public Health in Socio-Cultural Determinants. Yogyakarta: CV Budi Utama; 2018

8. Wedho MM. The Influence of socio-cultural factors, community participation, and factors local government budget policy against the leap of infant mortality reduction in Ngada and Kupang regencies. J Info Kesehatan. 2017;15(1):397-416. Available from: http://www.jurnal.poltekeskupang.ac.id/index.php/infokes/ article/view/156/152 [Last accessed on 2021 Jun 15].

9. Pratiwi NL, Roosihermiatie B, Hargono R. Determinant factors of health culture in pulmonary tuberculosis transmission. Bu Penelitian Sistem Kesehatan. 2012;15(1):26-37. https://doi. org/10.22435/bpsk.v15i1Jan.2974

10. Jauhari J. Fulfillment of sleep rest needs and its impact on health in early childhood. J Smart Paud. 2020;3(2):89-96. https://doi. org/10.36709/jspaud.v3i2.11731

11. Taek MM. Ethnomedicine of Traditional Medicine of the Tetun Community in West Timor. Kupang: LPHK \& Unwira Press; 2020.

12. Herlan H, Praptantya DB, Juliansyah V, Efriani E, Dewantara JA. Concepts of health and sickness in ethnic Dayak culture. Etnoreflika J Soc Cult. 2020;9(1):24-38. https://doi.org/10.33772/ etnoreflika.v9i1.720

13. Harsuki H. Recent Sports Developments. Jakarta: PT King Grafindo Persada; 2003.

14. Apituley TL, Damajanty HC, Pangemanan DH, Sapulete IM. The effect of sport on Coronavirus disease 2019. Biomed J. 2021;13(1):111-7. https://doi.org/10.35790/ jbm.13.1.2021.31752

15. Potter PA, Perry GA, Stockert PA, Hall AM. Fundamentals of Nursing: Concepts, Process, and Practice. New York: Elsevier; 2020

16. Suwarna $\mathrm{AH}$, Widiyanto $\mathrm{W}$. Differences in sleep patterns between the trained and untrained groups trained. Medikora. 2016;15(1):85-95. https://doi.org/10.21831/medikora. v15i1.10073

17. Elfiky I. Positive Thinking Therapy. Jakarta: Zaman Publisher; 2009.

18. Sumarsih T, Wahyuningsih T, Sawiji S. The Effect of Spiritual Relaxation on Changes in Anxiety and Stress Levels of Pulmonary Tuberculosis Patients at PKU Muhammadiyah Hospital Sruweng. Proceedings of the $10^{\text {th }}$ University Research Colloqium 2019 Muhammadiyah Gombong College of Health Sciences; 2019. Available from: http://www.repository.urecol. org/index.php/proceeding/article/view/703/686 [Last accessed on 2021 Jul 05].

19. Neonbasu G. Culture: An Agenda within the Framework of the Island of Timor and its Surroundings. Jakarta: PT Gramedia Pustaka; 2013.

20. Tule P. Getting to Know Keo Culture: Fairy Tales, Rituals and Social Organizations. Jakarta: Apix Printing; 2019.

21. Herniti E. The Javanese trust in witchcraft, Wangsit, and spirits according to the perspective of Edwards Evans-Pritchard. Thaqãfiyyãt. 2012;13(2):385-400. Available from: http://www. ejournal.uin-suka.ac.id/adab/thaqafiyyat/article/view/77 [Last accessed on 2021 Jul 14].

22. Badrujaman I. Sociology for Nursing Students. Jakarta: Trans Info Media; 2008.

23. Antonius B. The Conscience of the Buna. Kupang: Gita Kasih; 2011.

24. Seran ST. Traditional Government System in Belu. Kupang: Department of Culture and East Nusa Tenggara Province Tourism; 2010.

25. Djawa AR. Marapu ritual in East Sumba community. Avatara E J Pendidikan Sejarah. 2014;2(1):71-85. Available from: https:// www.core.ac.uk/download/pdf/230694051.pdf [Last accessed on 2021 Apr 12].

26. Lesmana $\mathrm{H}$, Alfianur A, Utami PA, Retnowati $\mathrm{Y}$, Darni D. Traditional medicine in the Tidung community of Tarakan city: Study qualitative local wisdom in the health sector. Medisains J IImiah IImu-IImu Kesehatan. 2018;16(1):31-41. Available from: http://www.jurnalnasional.ump.ac.id/index.php/medisains/ article/viewfile/2161/1957 [Last accessed on 2021 Jun 25]. https://doi.org/10.30595/medisains.v16i1.2161 